\title{
ПІДВИЩЕННЯ ЕФЕКТИВНОСТІ УПРАВЛІННЯ ПРОЦЕСОМ ЕКСПАНДУВАННЯ КОМБІКОРМІВ
}

Improving the efficiency of process control ekspanduvannya

Шебалдін В.A. ${ }^{1}$ (Shebaldin V.)

${ }^{1}$ Orcid: $\underline{0000-0002-2496-6040}$

E-mail: shebaldin.v@gmail.com

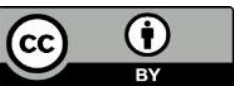

\section{Анотація}

Викладено пропозиції, а також результати їх реалізації у віртуальному середовищі MATLAB Simulink для підвищення ефективності автоматизованого керування процесом експандування комбікормів. Внаслідок чого гарантується стабільно висока якість експандованого комбікорму. Розглянутий технологічний процес експандування, виведені основні енергетичні параметри процесу експандування, які впливають на якість комбікорму

\section{Annotation}

Presents the proposals and the results of their implementation in a virtual environment MATLAB Simulink to improve the efficiency of automated process control expanded feed. As a result guaranteed consistently high quality expanded feed. Considered technological expanded derived basic energy parameters of expansion that affect the quality of feed

\section{Ключові слова}

Процес експандування, екстремальна обробка комбікормів, управління, регулювання, експандер , комбікорм.

\section{Вступ}

Висока вартість кормів для тварин, та якісне засвоєння їх, $є$ дуже важливим аспектом тваринництва. Зараз розроблено багато способів баротермічної обробки компонентів комбікормів, які дають корму нові поживні цінності, та підвищують засвоєння. Одним з найбільш популярних і якісних є експандування.

Технологічний процес експандування

Віддозовані вихідні сипучі компоненти комбікорму відповідно до рецептури і технологічних вимог обробляють рідкими добавками, гарячою водою або насиченим паром. Перед експандуванням зволожену суміш подають порціями в живильник-витримувач для рівномірного вологонасичення часток корму по всьому їх об'єму. Температура суміші перед експандуванням складає $50-77^{\circ} \mathrm{C}$.

Експандер це машина для приготування кормової сировини за рахунок екстремальної тепловологісної $\mathrm{i}$ механічної обробки, тиск в експандері досягає 30-40 ат і температура відповідно $120-130^{\circ} \mathrm{C}$ в пікових зонах, час перебування сировини близько 40с. 


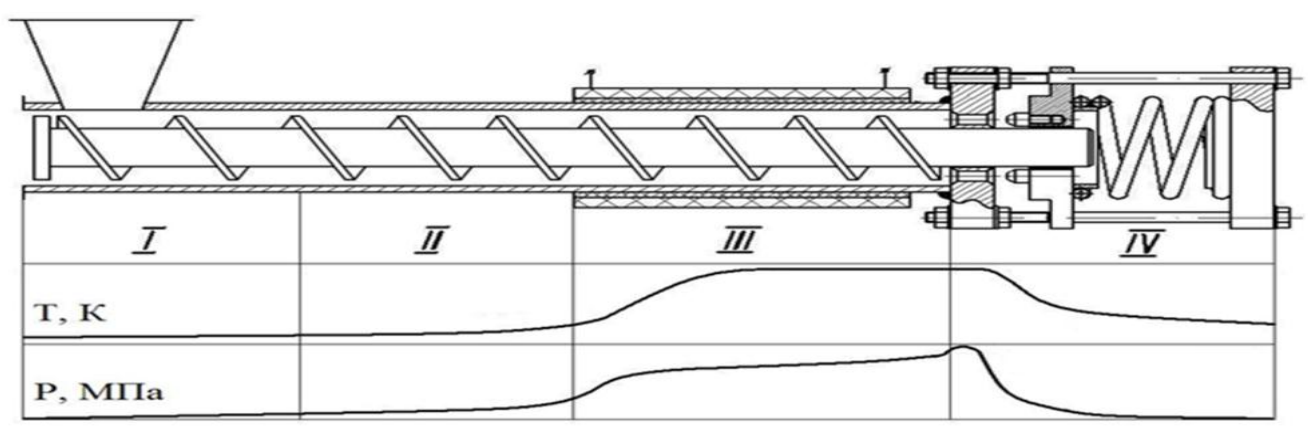

Рис. 1 Спрощена схема експандера, та зміна тиску і температури по його довжині

У 1й зоні відбувається перемішування і переміщення кормової суміші вздовж шнека та початок ущільнення. У 2 й зоні відбувається наростання тиску, пресування і руйнування часток корму. У Зй зоні подальше підвищення тиску і температури та це супроводжується переходом комбікорму у в'язкопластичний стан, вода переходить у критичний стан. У 4й зоні остаточне підвищення тиску до 30 ат і миттєве падіння тиску (до атмосферного) і за рахунок цього виникає розрив клітин комбікорму, вода розриває клітини і переходить в ненасичений пар.

Тиск створюється потужною пружиною, яка є фактично пропорційним регулятором тиску прямої дії з малим запізненням і великим коефіцієнтом передачі.

\section{Цілі і задачі керування}

Щоб керувати процесом експандування потрібно забезпечити: температуру комбікорму відповідно до технологічного регламенту, експлуатацію експандера у нормальних режимах. Це нам дасть: гарантовано стабільну високу якість експандованого комбікорму, зниження енергетичних затрат, зниження ймовірності виникнення аварійних ситуація, довговічність і бережність експлуатації дорогого обладнання і приводної частини експандера.

Для розв'язку такої проблеми був примінений спосіб каскадної структури системи керування із стабілізацією струму у внутрішньому контурі та контур зворотного зв’язку який стабілізує температуру на заданому значенні.

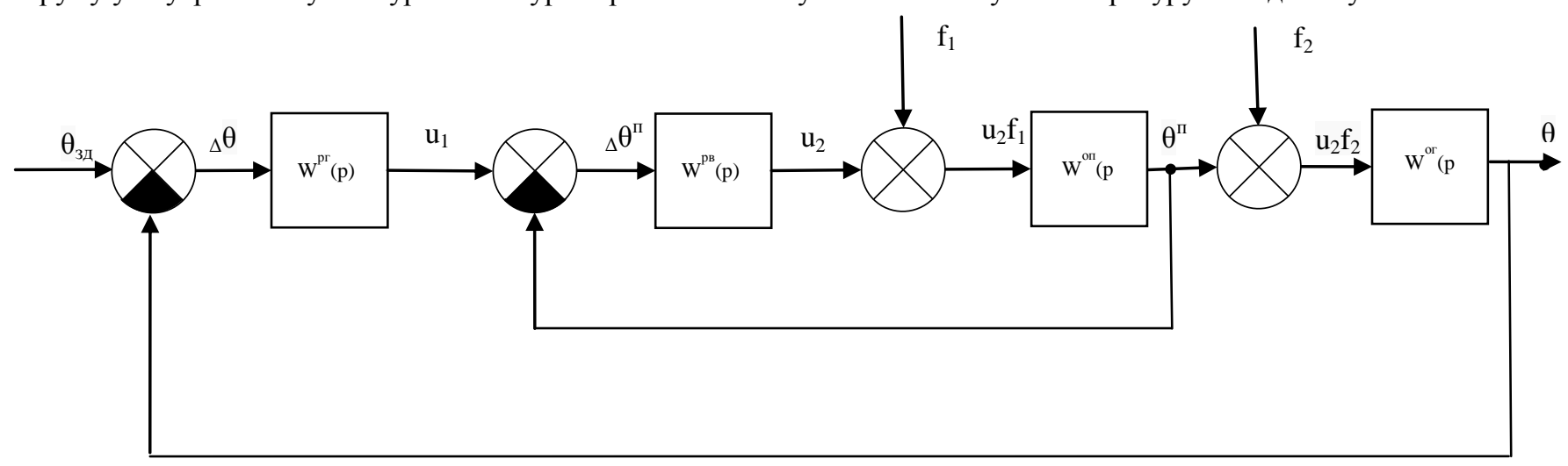

Рис. 2 Структурна схема моделі експандування зі стабілізацією контуру струму та температури

Була розроблена імітаційної модель процесу експандування зі стабілізацією контуру струму та температури. 


\section{СТУДЕНТСЬКА НАУКА STUDENT SCIENCE}

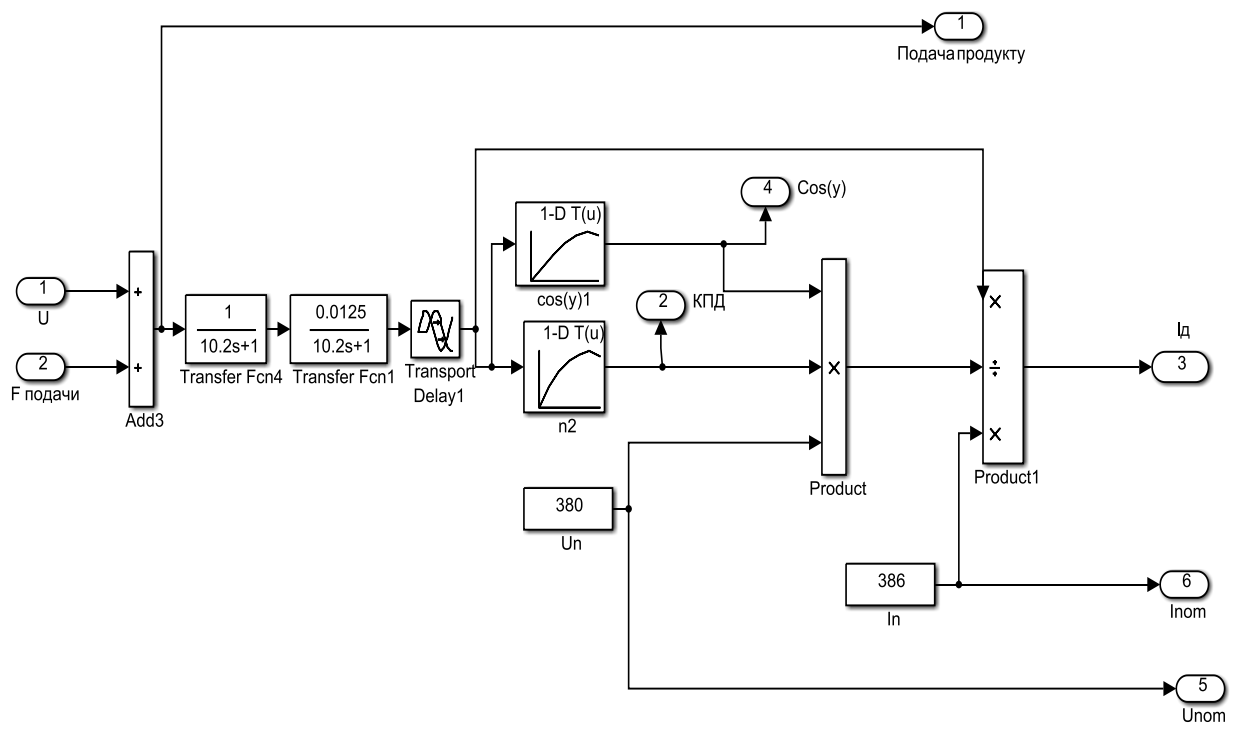

Рис. 3 Реалізація Схеми імітаційної моделі навантаження на приводний електродвигун

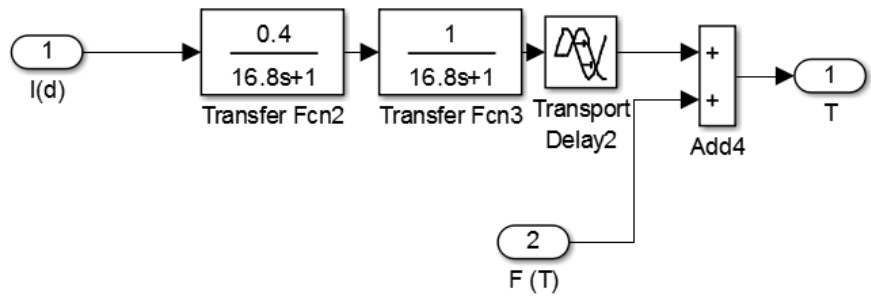

Рис. 4 Схема імітаціної моделі зміни температури головки експандера за рахунок переходу через неї комбікорму

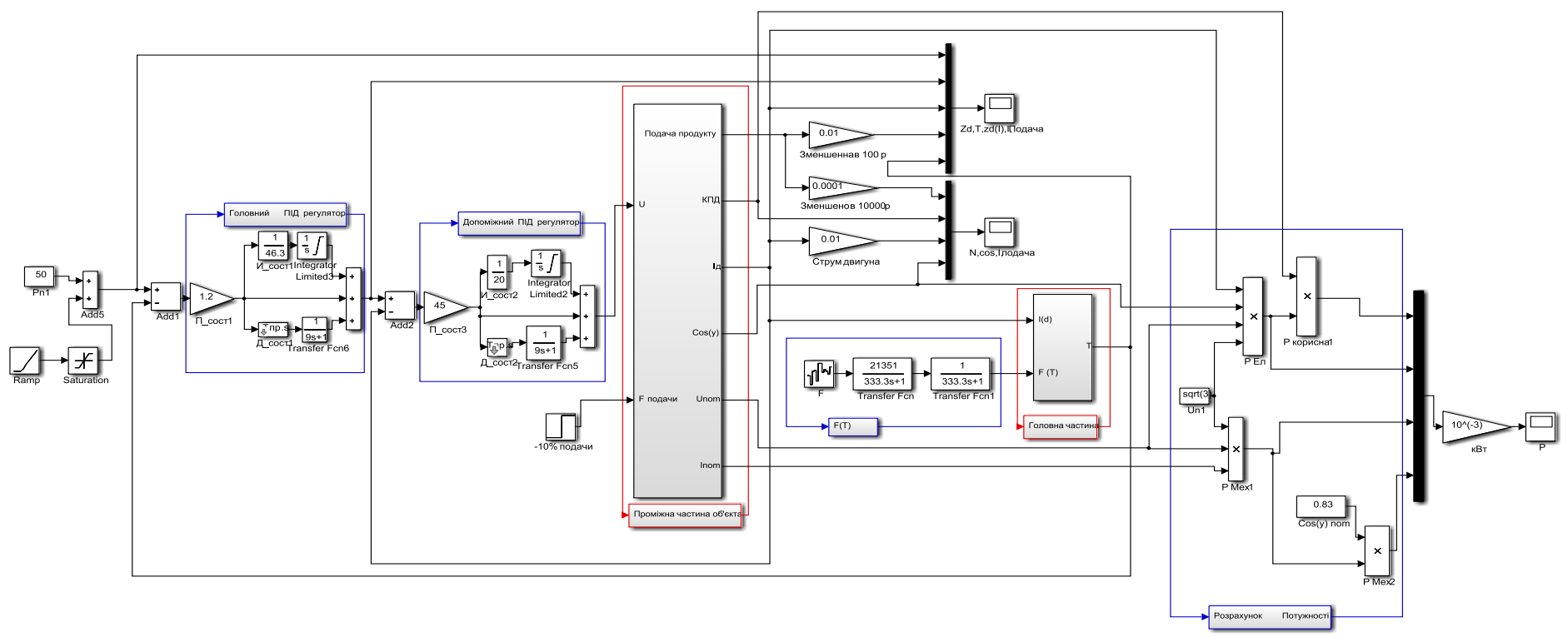

Рис. 5 Схема імітаційної моделі процесу експандування комбікормів каскадної структури 


\section{СТУДЕНТСЬКА НАУКА} STUDENT SCIENCE

Результати дослідження

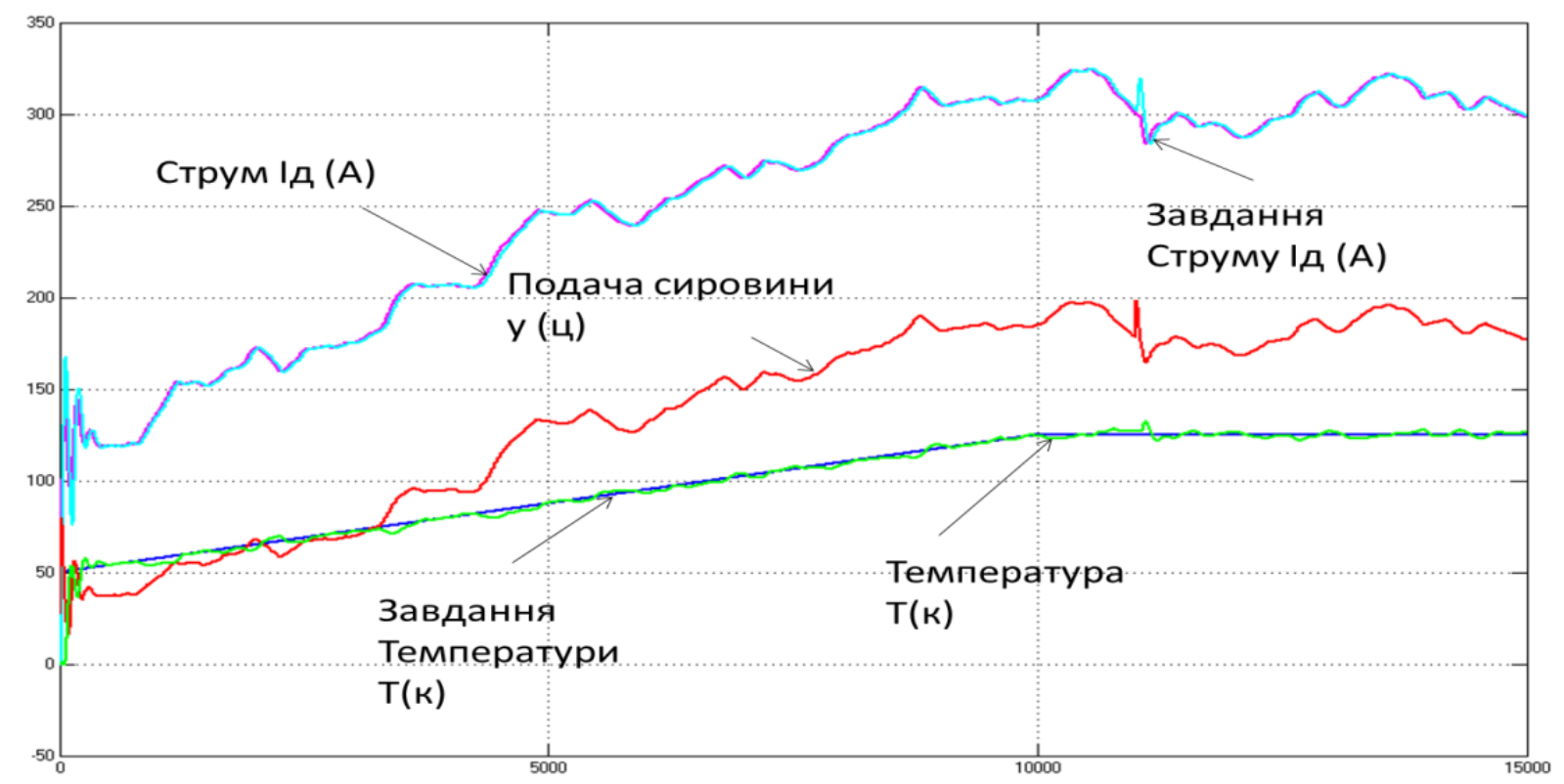

Рис. 6 Динаміка зміни основних проміжних параметрів

На графіку зображені основні змінні процесу. Температура і задане значення відповідають завданню. Реалізовано вхід в експлуатацію і вихід в номінальний режим, завдання температури змінюється поступово щоб усі деталі експандера прогрілись і встановився процес теплообміну між матеріалом і продуктом. Тому система керування забезпечує поступове підвищення температури і вихід на задане значення. При цьому струм навантаження росте, і досягає номінального режиму.

Розглянемо приклад, коли продукт поступатиме густим:

- струм навантаження виросте;

- продукт буде перегріватись;

• будуть додатково руйнуватись корисні речовини, вітаміни.

Каскадна система повинна цей струм стабілізуати, щоб забезпечувати задане значення. По струму процеси йдуть швидко, а по температурі повільно тому що йде прогрів масивної головки. Повної відповідності між струмом і температурою немає, але в певному приближенні відповідність є. Тому використовується каскадна структура, вона тримає заданий рівень струму, але якщо температура при цьому буде змінюватись то завдання струму буде автоматично настроюватись, щоб температура була відповідною регламенту. Кожна сировина має свої особливості і ці регламенти будуть по різному проявлятись. 


\section{СТУДЕНТСЬКА НАУКА} STUDENT SCIENCE

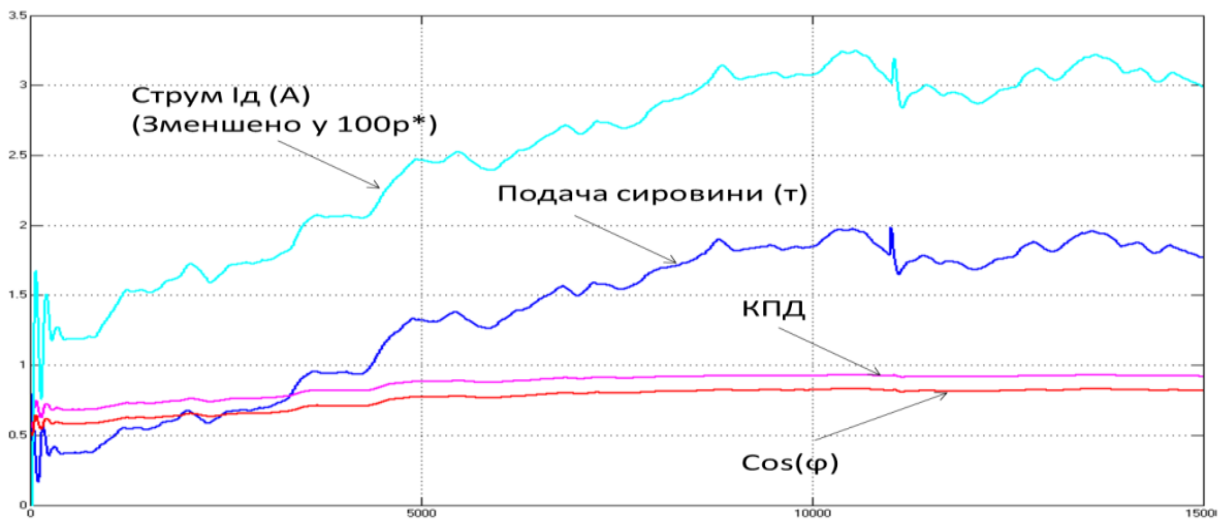

Рис. 7 Динаміка зміни складових енергоспоживання приводним електродвигуном
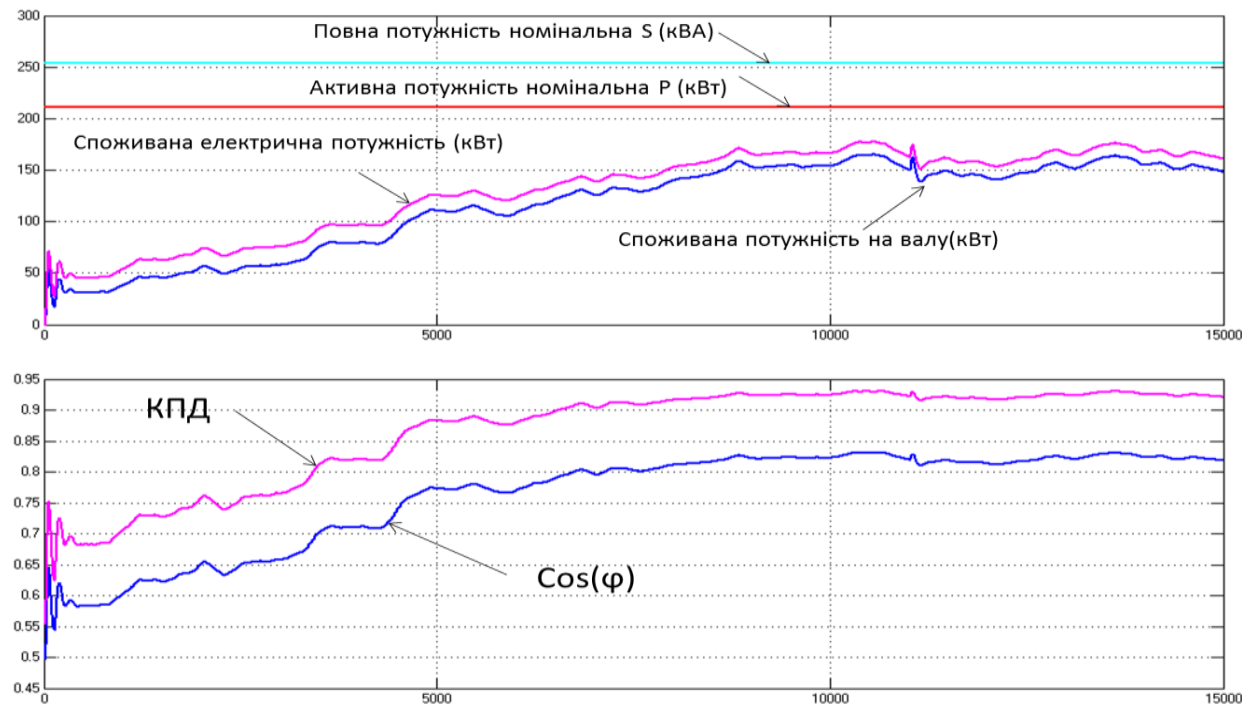

Рис. 8 Динаміка зміни номінальної і використаної потужностей. КПД і $\operatorname{Cos}(\phi)$

\section{Висновок}

Використання запропонованого способу автоматично керованого процесом експандування підвищило ефективність використання енергії, гарантує стабільно високу якість виробництва комбікорму і знизило експлуатаційні витрати, що дозволяє їх рекомендувати до широкого застосування.

Науковий керівник д.т.н., проф. Хобін В.А.

\section{Література}

1. «Овен» «Обладнання для автоматизації»/ http://www.owen.ru/21119386

2. [Руководство по технологии комбикормовой продукции с основами кормления животных/ В.А.Афанасьев.: Воронеж, 2007 . - С. 270-272

3. Конспект курса лекций по дисциплине “Теория автоматического управления” (часть I)- Хобин В.А. ОГАПТ. Одесса - 2008 г.

4. Конспект курса лекций по дисциплине “Специальные разделы теории управления” - Хобин В.А. ОГАПТ. Одесса - 2010 г.

5. Терехов В.М. Системы управления электроприводов: учебник / В.М. Терехов, О.И. Осипов. - М.: "Академия", 2005. - 301 с.

6. Автоматизированный электропривод промышленных установок / Г.Б. Онищенко, М.И. Аксенов, М.Н. Зарицкий та ін. За ред. Г.Б. Онищенко. - М.: РАСХН, 2001. - 520 с.

7. Ключев В.И. Электропривод и автоматизация общепромышленных мехнизмов: Учебник для вузов / В.И. Ключев, В.М. Терехов. - М.: Энергия, 1980. - 360 с. 


\section{References}

1. «Oven» «Oborudovaniye dlya»/ http://www.owen.ru/21119386];

2. [Rukovodstvo po tekhnologii kombikormovoy produktsii s osnovami kormleniya zhivotnykh / V.A.Afanas'yev .: Voronezh, 2007. - S. 270-272;

3. Konspekt kursa lektsiy po distsipline "Teoriya avtomaticheskogo upravleniya" (chast' I) - Khobin V.A. OGAPT. Odessa - 2008 g;

4. Konspekt kursa lektsiy po distsipline"Spetsial'nyye razdely teorii upravleniya"-Khobin V.A.OGAPT.Odessa-2010 g;

5. Terekhov V.M. Sistemy upravleniya elektroprivodov: uchebnik. - M .: "Akademiya", 2005. - 301 s.;

6. Avtomatizirovannyy elektroprivod promyshlennykh ustanovok / G.B. Onishchenko, M.I. Aksenov, M.N. Zaritskiy i dr. Pod red. G.B. Onishchenko. - M .: RASKHN, 2001. - $520 \mathrm{~s}$;

7. Klyuchevoy V.I. Elektroprivod i avtomatizatsiya obshchepromyshlennykh mekhnizmov: Uchebnik dlya vuzov / V.I. Klyuchevoy, V.M. Terekhov. - M .: Energiya, 1980. - 360 s.

\section{ЗАСТОСУВАННЯ МОДИФІКОВАНОГО МЕТОДУ ПІНЧ-АНАЛІЗУ ДЛЯ ОПТИМІЗАЦЇ̈ СТРУКТУРИ УСТАНОВКИ ПЕРВИННОЇ ПЕРЕРОБКИ НАФТИ}

Application of the modified pinch-analysis method for optimization of installation structure of primary oil refining

Кривда В.І., к.т.н. ${ }^{1}$, Максимов М.В., д.т.н., проф. ${ }^{2}$ (Kryvda V., Maksimov M.,)

1,2 Одеський національний політехнічний університет, м. Одеса

${ }^{1}$ ORCID: 0000-0001-6647-1049 ${ }^{2}$ ORCID: 0000-0002-3292-3112

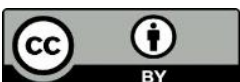

\section{Анотація}

Оптимальна структура установки первинної переробки нафти здатна створювати передумови для раціонального використання енергоресурсів на сучасному підприємстві. Крім того, така структура значно підвищує ефективність використання теплообмінного обладнання, що с безперечно важливим заходом 3 енергозбереження на виробництві по переробці нафтопродуктів. Заздалегідь правильно вибраний метод аналізу с запорукою чітких та вірних результатів при заданих початкових умовах. Напевно, що всі з відомих методів аналізу структур мають свої переваги, недоліки та особливості. В роботі пропонується посднати метод пінч-аналізу 3 методом ексергії-нетто. Така модифікація робить можливим використання переваг кожного 3 них для досягнення найкращих показників. Виконаний розрахунок параметричної чутливості функції 3 трьома змінними не виявив високої параметричної залежності приведених грошових та енергетичних витрат від заданих вихідних параметрів - температурного напору, вхідної температури сировини та кількості теплообмінних апаратів в установці первинної переробки нафти. Представлено загальну форму запису цільової функції задачі пошуку оптимальної структури установки первинної переробки нафти. Така цільова функція дозволяс комплексно аналізувати процес функціонування системи будь-якої технічної структури. Виявлено залежності приведених витрат в грошових та енергетичних одиницях від заданих вихідних параметрів. Визначено оптимальні значення цільових функцій і їх величини в крайніх точках області значень. Модифікований метод пінч-аналізу дозволяє порівнювати технікоекономічні показники 3 енергетичними результатами, які отримані після аналізу структури установки первинної переробки нафти.

\section{Abstract}

The optimum structure of installation of primary oil refining is capable to create pre-conditions for rational use of energy resources at the modern enterprise. Besides, such structure considerably increases efficiency of use of the 